\title{
Analisis Pengaruh Kinerja Keuangan Terhadap Nilai Perusahaan Yang Terdaftar Di Bursa Efek Indonesia
}

\author{
Allend Tio ${ }^{1}$, Argo Putra Prima ${ }^{2}$ \\ Universitas Putera Batam \\ alandtio21@gmail.com ${ }^{1}, \underline{\text { argo putraprima@yahoo.co.id }}{ }^{2}$
}

*Corresponding Author

Diajukan : 21 Desember 2021

Disetujui : 1 Januari 2022

Dipublikasi : 1 Januari 2022

\begin{abstract}
The aims of this research is to analyze and prove the impact of profitability as proxied by return on assets, liquidity proxied by current ratio and solvency as proxied by debt to equity ratio partially and simultaneously on firm value in mining companies that listed on IDX for the 20152020 period. The research was conducted with a quantitative approach, with a purposive sampling technique. The analysis technique used is multiple linear regression with partial test hypothesis testing ( $t$ test), simultaneous test ( $F$ test), and multiple determination coefficient test $(R 2)$ with the help of SPSS version 25 program. The results of the study show that 1) profitability is proven significant effect on firm value with a regression coefficient of -0.719 ; 2) liquidity is proven to have a significant effect on firm value with a regression coefficient of -1.160 ; 3) solvency has a significant effect on firm value with a regression coefficient of -1.354 ; and 4) profitability, liquidity and solvency proved to have a significant effect on firm value with a regression coefficient of 0.236. It is mean that profitability, liquidity, and solvency variables simultaneously and partially affect the firm value because the value of sig $<5 \%$. This proves that in a mining company to increase the value of the company, it must pay attention to the profitability, liquidity, and solvency of the company.
\end{abstract}

Keywords: Firm Value, Liquidity, Profitabililty, Solvability.

\section{PENDAHULUAN}

Persaingan bisnis yang ketat, menjadikan perusahaan harus berusaha mempertahankan pangsa pasar untuk memperoleh nilai perusahaan. Nilai industri yaitu harga yang mampu disetorkan calon pembeli apabila industri itu dijual (Franita, 2018: 7). Manajemen perusahaan melakukan berbagai kebijakan guna menaikan nilai perusahaan, salah satunya dengan meningkatkan kesejahteraan pemilik serta pemegang saham. Hal ini karena nilai perusahaan sebagai pendapat penanam modal pada jenjang kesuksesan industri, dengan cara dilihat dari harga saham. Sebuah perusahaan yang cukup mendominasi di Bursa Efek Indonesia (BEI) adalah sektor pertambangan. Preliminary perhitungan pada empat perusahaan pertambangan selama lima periode, diketahui perusahaan cenderung mengalami penurunan nilai perusahaan. Nilai perusahaan pada sektor pertambangan disajikan pada tabel berikut:

Tabel 1. Nilai Perusahaan Sektor Pertambangan Periode 2015-2020

\begin{tabular}{|l|c|c|c|c|c|c|}
\hline Kode Perusahaan & $\mathbf{2 0 1 5}$ & $\mathbf{2 0 1 6}$ & $\mathbf{2 0 1 7}$ & $\mathbf{2 0 1 8}$ & $\mathbf{2 0 1 9}$ & $\mathbf{2 0 2 0}$ \\
\hline ANTM & $0,13 \%$ & $0,13 \%$ & $0,13 \%$ & $0,12 \%$ & $0,13 \%$ & $0,13 \%$ \\
\hline RUIS & $0,23 \%$ & $0,21 \%$ & $0,20 \%$ & $0,19 \%$ & $0,18 \%$ & $0,17 \%$ \\
\hline PTBA & $0,06 \%$ & $0,05 \%$ & $0,04 \%$ & $0,01 \%$ & $0,01 \%$ & $0,01 \%$ \\
\hline MITI & $1,77 \%$ & $2,26 \%$ & $2,37 \%$ & $2,60 \%$ & $-16,90 \%$ & $-21,89 \%$ \\
\hline
\end{tabular}

Sumber: Laporan keuangan perusahaan di Bursa Efek Indonesia, diolah 
Berdasarkan tabel itu, dikatahui bahwa PT. Aneka Tambang Tbk (ANTM), PT. Radiant Utama Interinsco Tbk (RUIS), PT. Bukit Asam Tbk (PTBA) dan PT. Mitra Investindo Tbk (MITI) mengalami penurunan. Penurunan terjadi pada PT. Mitra Investindo Tbk yang mencapai $-21,89 \%$. Salah satu tujuan perusahaan ialah meningkatkan nilai perusahaan, dengan memaksimalkan kesejahteraan pemegang saham. Nilai perusahaan dapat ditentukan oleh harga sahamnya(Fauzia dan Amanah, 2016). Hal ini menunjukkan bahwa semakin tinggi harga saham suatu perusahaan maka semakin tinggi tingkat pengembalian bagi investor artinya jika nilai perusahaan turun maka return investor juga turun sehingga minat investor untuk berinvestasi akan turun. Terdapat aspek yang bisa berdampak pada tinggi rendahnya nilai, yaitu kinerja keuangan terdiri atas profitabilitas, likuiditas dan solvabilitas (Ningsih dan Sari, 2019 ; Fajaria dan Isnalita, 2018 ; Markonah, Salim dan Franciska, 2020).

Berdasarkan pendapat Septiana (2019:108), profitabilitas digunakan sebagai rasio dalam mengukur kekuatan perusahaan guna menghasilkan laba di tingkat penjualan, ekuitas serta aset tertentu. Faktor kedua yaitu likuiditas yang merupakan kemampuan untuk mencapai kewajiban keuangan dan wajib dicapai segara atau kewajiban jangka pendek industri (Ismanto, dkk., 2019:72). Suatu perusahaan mempunyai kekuatan untuk membayar utang jangka pendek, dapat dikatakan industri itu likuid sedangkan perusahaan yang belum bisa menyetorkan kewajiban jangka pendeknya dimaknai ilikuid. Fakor ketiga yaitu solvabilitas. Berdasarkan pendapat Septiana (2019:79), sovabilitas yaitu rasio keuangan guna dimanfaatkan untuk melihat kesanggupan perusahaan guna memenuhi kewajibannya, baik jangka pendek ataupun jangka panjang. Industri yang solvable akan memiliki aset yang lumayan dalam membayar seluruh kewajibannya. Lain hal, perusahan yang insovable tidak memiliki cukup kekayaan untuk membayar keseluruhan kewajibannya.

Penelitian terdahulu berkaitan dengan nilai perusahaan yang dipengaruhi profitabilitas, likuiditas, serta solvabilitas masih menunjukan adanya ketidakkonsistenan hasil penelitian. Penelitian yang dilakukan Markonah, Salim dan Franciska (2020), yang memperoleh hasil hahwa keuntungan yang diproksikan return on asset valid mempunyai dampak pada nilai perusahaan, sedangkan likuiditas terbukti tak berdampak pada nilai perusahaan. Berlawanan dengan studi yang dilakukan Kadim dan Sunardi (2019), menerangkan kalau profitabilitas yang diproksikan dengan return on asset terbukti tak signifikan pada nilai perusahaan. Hasil berbeda juga diperoleh pada studi yang dilakukan Sukarya dan Baskara (2019), menunjukkan jika likuiditas berpengaruh pada nilai perusahaan. Studi lain dilakukan Ningsih dan Sari (2019), dimana solvabilitas terbukti tak mempunyai kontribusi signifikan pada nilai industri. Perihal tersebut membuktikan jika tinggi rendahnya solvabilitas, tidak mencerminkan pada naik turunnya nilai perusahaan. Lain hal pada penelitian Panggabean, dkk (2018), yang membuktikan solvabilitas memiliki kontribusi pada nilai perusahaan. Berdasarkan fenomena gap serta research gap maka diperlukan penelitian lebih lanjut mengenai pengaruh dari profitabilas, likuiditas, serta solvabilitas terhadap nilai perusahaan.

\section{Teori Agensi}

\section{STUDI LITERATUR}

Hubungan kerjasama antara pemegang saham dan manajemen dalam bisnis dijelaskan oleh teori keagenan. Hubungan keagenan ada karena pemegang saham menyewa dan mendelegasikan wewenang kepada orang lain untuk melakukan layanan dan membuat keputusan bisnis atas nama mereka (Anthony \& Govindarajan, 2007). Selain itu, teori keagenan menjelaskan bagaimana kontrak dan insentif antara prinsipal dan agen bekerja untuk mencapai keselarasan tujuan. Kesejahteraan pemegang saham akan meningkat seiring kenaikan tingkat return perusahaan oleh karena itu manajemen akan selalu berusahaa untuk meningkatkan tingkat return yang diharapkan guna meningkatkan kesejahteraan pemegang saham. 


\section{Profitabilitas}

Profitabilitas yaitu hasil akhir serangkaian kebijakan serta keputusan yang dipilih dari manajemen perusahaan (Markonah, Salim dan Franciska, 2020). Menurut Hery (2016:150), Profitabilitas bertjuan guna memahami kemampuan perusahaan untuk mengendalikan laba. Kemudian, mengetahui efektifitas manajemen perusahaan untuk menjalankan kegiatan usaha. Cara guna mengukur besaran tingkat profitabilitas dalam perusahaan, dengan menggunakan ROA (Septiana, 2019: 109-111). Return on Aset (ROA) menghitung kapabilitas industri memperoleh profit bersih di tingkatan aset tertentu. Adapun rumus ROA ialah :

$$
R O A=\frac{\text { LabaBersih }}{\text { TotalAset }}
$$

\section{Likuiditas}

Menurut Septiana (2019:65), likuiditas merupakan kapabilitas perusahaan guna membayarkan hutang jangka pendek. Likuiditas merupakan kapabilitas industri pada membayar kewajiban yang wajib digapai segera atau kewajiban janga pendek industri (Kariyoto, 2017:189). Untuk mengetahui tingkat likuiditas perusahaan menggunakan rasio lancar yang dapat (Septiana, 2019:66-68). Rasio ini memperlihatkan bagaimana aset lancar menutupi kewajiban lancar. Dengan kata lain, aset lancar harus lebih besar dari total kewajiban lancar. Rasio tersebut dapat dinyatakan sebagai berikut:

$$
\text { Rasio lancar }=\frac{\text { Aktiva lancar }}{\text { Hutang lancar }}
$$

\section{Solvabilitas}

Berdasarkan pendapat Septiana (2019:79), rasio solvabilitas dipakai guna melihat kemapuan dari perusahaan untuk membayar semua kewajibannya, apabila perusahaan diberhentikan. Cara yang digunakan untuk mengukur solvabilitas menurut Septiana (2019:82-84) yaitu Debt to equity ratio (DER) Rasio ini mereflesikan modal perusahaan mampu menutupi keseluruhan utang. Rasio ini juga memperlihatkan tingkatan perusahaan dibiayai oleh utang. Apabila semakin kecil, maka semakin baik dikarenakan modal lebih tinggi dari total liabilitias perusahaan. Adapun rasio ini bisa diformulasikan antara lain:

$$
\text { Debt to equity ratio }=\frac{\text { Total utang }}{\text { Total equity }}
$$

\section{Nilai Perusahaan}

Nilai perusahaan sebagai tujuan utama perusahaan tersebut didirikan. Menurut Franita (2018:6), nilai perusahaan yaitu nilai sekarang yang terdiri atas serangkaian arus kas masuk dan dapat menghasilkan perusahaan di masa depan. Hal ini berarti kalau nilai industri sebagai nilai pasar yang memakmurkan stockholders yang maksimun, jika harga saham naik.

Salah satu tujuan dalam suatu industri ialah meningkatkan nilai perusahaan serta mengoptimalkan kemakmuran stockholders. Nilai perusahaan tercermin pada harga saham 
perusahaan tersebut. Dengan demikian, semakin besar harga saham suatu perusahaan, maka akan semakin besar pula tingkat pengembalian investor (Fauzia dan Amanah, 2016) . Kinerja perusahaan secara keseluruhan dapat diukur dengan melihat rasio peringkat. Dimungkinkan untuk menghitung nilai perusahaan menggunakan rasio harga terhadap nilai buku (PBV) (Fauzia dan Amanah, 2016):

$$
\text { PBV Ratio }=\frac{\text { Harga saham }}{\text { Book Value }}
$$

\section{Perumusan Hipotesis}

Hubungan Antara Profitabilitas Dengan Nilai Perusahaan

Rasio profitabilitas bermaksud guna mengidentifikasi kapasitas suatu industri pada mengandalikan profit, selain itu rasio profitabilitas pula bermaksud guna mengetahui jenjang efektifitas pengelolaan ketika melaksanakan operasional industri (Hery, 2016:150). Rasio profitabilitas bisa dipakai tidak hanya guna pihak internal perusahaan, namun pihak eksternal perusahaan memerlukan rasio profitabilitas sebagai dasar pengambilan keputusan. Berdasarkan studi yang dilakukan Fajaria dan Isnalita (2018), yang membuktikan kalau keuntungan mempunyai peran yang signifikan pada tinggi rendahnya nilai industri. Perusahaan dengan profit yang baik, akan menjadi perhatian pasar sehingga harga saham juga akan mengalami peningkatan. Mengingat setiap pemilik modal, menginginkan pendapatan atau dividen dari modal yang ditanamkan kepada perusahaan.

\section{Hubungan Antara Likuiditas Dengan Nilai Perusahaan}

Likuiditas merupakan kapasitas sebuah industri dalam memenuhi kewajiban keuangan yang wajib dipenuhi atau kewajiban janga pendek industri (Kariyoto, 2017:189). Suatu perusahaan mempunyai kekuatan untuk membayar jangka pendeknya, Ketika suatu perusahaan mampu membayar hutang jangka pendeknya, dikatakan likuid, sedangkan perusahaan yang tidak likuid tidak bisa. Dalam kebanyakan kasus, kewajiban jangka pendek dievaluasi selama satu tahun pada suatu waktu. Berdasarkan studi yang dilakukan Sukarya dan Baskara (2019), diperoleh hasil kalau likuiditas memiliki kontribusi signifikan kepada naik turunnya nilai industri. Pasar akan merespon apabila perusahaan memiliki likuiditas yang cukup stabil dan cenderung meningkat. Mengingat perusahaan yang memilik likuiditas rendah, akan diharapkan pada tingginya resiko bisnis dan cenderung dihindari oleh investor.

\section{Hubungan Antara Solvabilitas Dengan Nilai Perusahaan}

Rasio solvabiltas sebagai rasio yang dapat dipakai buat menghitung seberapa besar aset industri dapat membiayai liabilitas perusahaan (Kasmir, 2020:151). Dimana berapa besar beban utang yang menjadi tanggungjawab industri diselisihkan dengan aktiva yang dimilikinya. Secara umum rasio ini dapat dipakai guna mengamati kapasitas industri ketika membayar keseluruhan kewajibannya. Berdasarkan studi yang dilakukan Markonah, Salim dan Franciska (2020), diperoleh hasil bahwa solvabilitas memiliki kontribusi pada naik turunnya nilai perusahaan. Dalam catatan atas laporan keuangan, rasio solvabilitas membantu manajemen dan investor lebih memahami profil risiko struktur modal perusahaan. Jenjang risiko yang tinggi, akan menjadi pertimbangan investor dalam menanamkan modalnya.

Berikut ini adalah kerangka pemikiran penelitian, yang diturunkan dari informasi yang diberikan di atas: 
Owner: Riset \& Jurnal Akuntansi

e-ISSN : 2548-9224 |p-ISSN : 2548-7507

Volume 6 Nomor 1, Januari 2022

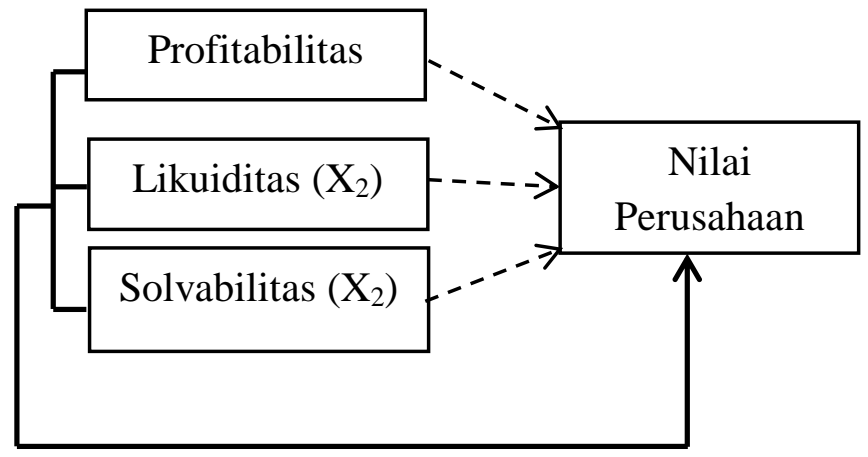

Gambar 1. Kerangka Pemikirian berikut:

Berdasarkan kerangka pemikiran tersebut maka hipotesis penelitian ini adalah sebagai

$\mathrm{H}_{1} \quad$ : profitabilitas berpengaruh terhadap nilai perusahaan

$\mathrm{H}_{2} \quad$ : likuiditas berpengaruh terhadap nilai perusahaan

$\mathrm{H}_{3} \quad$ : solvabilitas berpengaruh terhadap nilai perusahaan

$\mathrm{H}_{4}$ : profitabilitas, likuiditas dan solvabilitas berpengaruh terhadap nilai perusahaan.

\section{Populasi dan Sampel}

\section{METODE}

Populasi riset kali ini yaitu industri pertambangan listed pada Bursa Efek Indonesia dari tahun 2015 s/d tahun 2020 sekitar 47 industri. Metode perolehan sampel yang dipakai yaitu metode purpose sampling. Menurut penjelasan Yusuf (2017:153), tujuan dari teknologi sampling adalah untuk menentukan sampel dengan standar yang sudah ditetapkan sampai dapat memenuhi data yang diperlukan oleh penulis. Dibawah ini adalah standar sampel untuk riset ini:

1. Industri sektor pertambangan yang teregistrasi di BEI tahun 2015-2020.

2. Industri yang menerbitkan financial statement secara lengkap sepanjang masa penelitian.

3. Industri yang menerbitkan financial statement dalam satuan mata uang rupiah.

Tabel 2. Data Perusahaan yang Menjadi Sampel Penelitian

\begin{tabular}{clc}
\hline No & \multicolumn{1}{c}{ Keterangan } & Jumlah \\
\hline 1 & $\begin{array}{l}\text { Perusahaan Sektor pertambangan yang terdaftar di BEI periode 2015- } \\
2020 .\end{array}$ & 47 \\
\hline 2 & $\begin{array}{l}\text { Perusahaan yang menerbitkan laporan keuangan tidak lengkap di BEI } \\
\text { periode 2015-2020. }\end{array}$ & $(31)$ \\
\hline Jumlah sampel yang sesuai dengan kriteria & 16 \\
\hline Tahun pengamatan & 6 \\
\hline Total sampel penelitian & 96 \\
\hline
\end{tabular}

\section{Jenis dan Pengumpulan Data}

Tipe data yang dipilih oleh penulis ialah sekunder berupa data kuantitatif ialah financial statements industri pertambangan masa 2015-2020 yang diperoleh melalui web site BEI.

\section{Teknik Analisis Data}

\section{Analisis Statistik Deskriptif}

Menggambarkan data dari segi mean, standar deviasi, nilai terendah dan maksimum, dan sebagainya, Ghozali (2011: 19) menjelaskan statistik deskriptif. Yang berarti pendekatan deskriptif, bukan uji hipotesis, yang dapat memberikan informasi tentang data yang dimiliki.

Uji Asumsi Klasik 
Owner: Riset \& Jurnal Akuntansi

e-ISSN : 2548-9224 | p-ISSN : 2548-7507

Volume 6 Nomor 1, Januari 2022

DOI : https://doi.org/10.33395/owner.v6i1.605

Uji heteroskedastisitas, uji multikolinieritas, serta uji normalitas ialah termasuk uji asumsi klasik dengan bantuan program SPSS 25.

Analisis Regresi Linier Berganda

Menurut Purnomo (2017: 147), Arah keterkaitan antar variabel dan pengaruh satu variabel terhadap variabel lainnya ditentukan melalui penerapan analisis regresi linier berganda (MLRA). Persamaan regresi penelitian ini ditulis sebagai berikut:

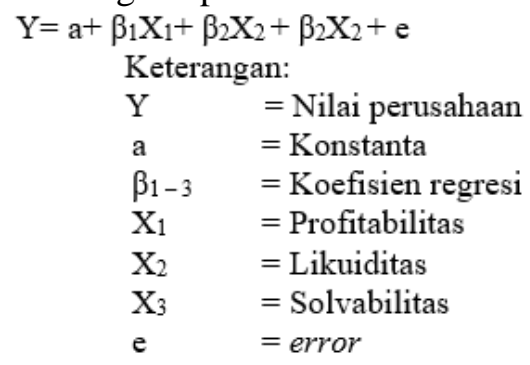

Uji Hipotesis

1. Uji Parsial

Menurut Purnomo (2017: 217), uji parsial bermaksud guna mengetahui terdapat tidaknya dampak pribadi antara variabel independe dan variabel dependen. Jika nilai sig. Menurut hasil perhitungan kurang dari 0,05 atau thitung > ttabel, alhasil H0 tak diterima dan H1 diterima. Dengan kata lain, variabel bebas memiliki pengaruh parsial pada variabel terikat. Dan sebaliknya, jika lebih besar dari ini alhasil H0 diterima dan H1 tak diterima. Dengan kata lain, variabel bebas tidak berdampak secara parsial pada variabel terikat.

2. Uji Simultan

Menurut Purnomo (2017: 216), pengujian bersamaan bermaksud guna mengetahui terdapat tidaknya dampak dengan antara variabel independen dengan variabel dependen. Apabila jenjang signifikansi nilai $\mathrm{F}$ hitung berdasarkan hasil perhitungan $<0,05$, atau Fhitung > Ftabel, alhasil H0 ditolak dan terima H1. Berarti variabel independen mempengaruhi variabel terikat dengan cara bersamaan. Dan sebaliknya, jika Fhitung > dari H0 diterima dan H1 ditolak.

3. Uji Koefisien Determinasi Berganda $\left(\mathrm{R}^{2}\right)$

Sesuai dengan opini Suyono (2018:84), tes R2 bermaksud guna mengenali kapasitas model guna menjelaskan dampak dua variabel. Jika $\mathrm{R}^{2}$ mendekati 1 maka variabel bebas berpengaruh kuat terhadap nilai perusahaan.

\section{Statistik Deskriptif}

\section{HASIL}

Terdapat juga temuan statistif deskriptif pada riset ini ialah antara lain:

Tabel 3. Statistik Deskriptif

\begin{tabular}{l|r|r|r|r|r} 
& N & Minimum & Maximum & \multicolumn{1}{c}{ Mean } & Std. Deviation \\
\hline ROA & 96 & .00 & 4.98 & .8348 & .78725 \\
\hline CR & 96 & .24 & 20.17 & 2.5256 & 2.49438 \\
\hline DER & 96 & -5.91 & 8.35 & .9948 & 1.50923 \\
\hline Nilai Perusahaan & 96 & -21.89 & 40.33 & 2.2845 & 9.86616 \\
\hline Valid N (listwise) & 96 & & & & \\
\hline Sum
\end{tabular}

Sumber: Hasil Output SPSS (2021) 
Owner: Riset \& Jurnal Akuntansi

e-ISSN : 2548-9224 | p-ISSN : 2548-7507

Volume 6 Nomor 1, Januari 2022

DOI : https://doi.org/10.33395/owner.v6i1.605

\section{Uji Asumsi Klasik}

Uji Normalitas

Nilai signifikansi pada One-Sample Kolmogorov-Smirnov Test sebesar 0,060 > 0,05. Perihal ini menunjukkan kalau data dalam model regresi berdistribusi normal serta dapat dipakai gina analisa berkelanjutan. Dari data awal yang diamati yaitu 96 data, dari hasil tranformasi dengan menggunakan LN diperoleh data sebanyak 88 data yang normal. Sehingga analisa selanjutnya menggunakan data yang telah ditransformasikan dalam bentuk LN.

Uji Multikolinieritas

Peneliti melakukan uji hipotesis multikolinearitas untuk mengetahui penyimpangan model regresi. Asumsi multikolinearitas dapat dihindari, menurut Gani dan Amalia (2015:126), jika nilai VIF dan nilai Tolerance keduanya lebih kecil atau sama dengan 0,01. Semua nilai VIF variabel kurang dari sepuluh, menunjukkan adanya masalah. Pengujian hipotesis klasik dalam penelitian ini tidak menemukan bukti adanya bias multikolinearitas.

Uji Heteroskedastisitas

Uji heteroskedastisitas dapat dilaksanakan dengan menggunakan tes Glejser. Kriteria penentuan ketetapan dapat dinyatakan terhindar dari masalah heteroskedastisitas apabila nilai signifikansi $\geq 0,05$. Setiap variabel independen memperoleh nilai signifikansi $>0,05$. Artinya model regresi dalam penelitian ini tak mengalami gejala heteroskedastisitas.

\section{Analisis Regresi Linier Berganda}

Tabel 4. Hasil Analisis Regresi Linier Berganda

\section{Coefficients $^{\mathrm{a}}$}

\begin{tabular}{|c|c|c|c|c|}
\hline \multirow{2}{*}{\multicolumn{2}{|c|}{ Model }} & \multicolumn{2}{|c|}{ Unstandardized Coefficients } & \multirow{2}{*}{$\begin{array}{c}\text { Standardized Coefficients } \\
\text { Beta }\end{array}$} \\
\hline & & B & Std. Error & \\
\hline 1 & (Constant) & -1.758 & .312 & \\
\hline & $\ln \mathrm{ROA}$ & -.719 & .193 & -.376 \\
\hline & $\ln \mathrm{CR}$ & -1.160 & .457 & -.393 \\
\hline & $\ln \mathrm{DER}$ & -1.354 & .325 & -.660 \\
\hline
\end{tabular}

a. Dependent Variable: In_Nilai_Perusahaan

Sumber: Hasil Output SPSS (2021)

Dalam tabel itu tentang hasil pengolahan SPSS, alhasil bisa dirancang persamaan regresi berganda yaitu:

$$
Y=-1,758-0,719 X_{1}-1,160 X_{2}-1,354 X_{3}+e
$$

\section{Pengujian Hipotesis}

Uji hipotesis pada riset ini dijalankan dengan ditunjung aplikasi SPSS versi 25. Dibawah ini penjelasan masing-masingpengujian hipotesis dalam penelitian ini:

Uji Parsial (Uji t)

Berikut hasil uji parsial (uji t) pada riset ini ini:

Tabel 5. Hasil Parsial Uji t 


\section{Coefficients $^{\mathrm{a}}$}

\begin{tabular}{ll|r|r} 
Model & \multicolumn{2}{c}{ Sig. } \\
\hline 1 & (Constant) & -5.626 & .000 \\
& ln ROA & -3.720 & .000 \\
\hline & $\ln$ CR & -2.538 & .013 \\
\hline $\ln$ DER & -4.161 & .000 \\
\hline
\end{tabular}

a. Dependent Variable: In Nilai Perusahaan

Sumber: Hasil Output SPSS (2021)

Variabel profitabilitas (ROA) mendapat poin sigifikansi sekitar $0,000<0,05$. Berarti dengan cara parsial profitabilitas berdampak signifikan pada nilai perusahaan. Variabel likuiditas (CR) mendapat poin signifikansi sekitar $0,013<0,05$. Berarti dengan cara parsial likuiditas berdampak signifikan pada nilai perusahaan.Variabel solvabilitas (DER) mendapat poin sigifikansi sekitar $0,000<0,05$. Berarti secara parsial solvabilitas berdampak signifikan pada nilai perusahaan.

Uji Simultan (Uji F)

Dibawah ini temuan uji simultan pada riset ini:

\begin{tabular}{|c|c|c|c|c|c|c|}
\hline \multirow{2}{*}{\multicolumn{2}{|c|}{ Model }} & & & & & \\
\hline & & $\begin{array}{l}\text { Sum of } \\
\text { Squares }\end{array}$ & df & Mean Square & $\mathrm{F}$ & Sig. \\
\hline \multirow[t]{3}{*}{1} & Regression & 76.817 & 3 & 25.606 & 8.628 & $.000^{\mathrm{b}}$ \\
\hline & Residual & 249.281 & 84 & 2.968 & & \\
\hline & Total & 326.098 & 87 & & & \\
\hline
\end{tabular}

a. Dependent Variable: In_Nilai_Perusahaan

b. Predictors: (Constant), $\overline{\ln } \_\mathrm{DER}, \ln \_\mathrm{ROA}, \ln \_\mathrm{CR}$

Sumber: Hasil Output SPSS (2021)

Tingkat signifikansi ditetapkan sebesar $0,000<0,05$ berlandaskan data dalam tabel di atas. Nilai perusahaan dipengaruhi oleh ketiga faktor tersebut secara bersamaan, yaitu profitabilitas (ROA), likuiditas (CR) dan solvabilitas (DER).

Uji Koefisien Determinasi Berganda $\left(\mathrm{R}^{2}\right)$

$R$ Square yang dihasilkan senilai 0,236 atau $23,6 \%$ yang menunjukkan apabila variabel nilai industri bisa diuraikan dari variabel profitabilitas, likuiditas dan solvabilitas sekitar 23,6\% serta selebihnya diuraikan variabel lain tak termasuk pada riset.

\section{Pengaruh Profitabilitas Terhadap Nilai Perusahaan}

\section{PEMBAHASAN}

Berdasarkan temuan analisa data, diperoleh hasil variabel profitabilitas (ROA) memperoleh poin sigifikansi sekitar $0,000<0,05$. Artinya profitabilitas dihitung melalui return on asset berdampak signifikan terhadap nilai industri pertambangan di BEI, atau $\mathrm{H}_{1}$ diterima. Nilai koefisien variabel profitabilitas (ROA) sebesar 0,719 dengan nilai negatif. Artinya setiap kenaikan satu satuan variabel profitabilitas, akan berdampak penurunan pada variabel nilai perusahaan sebesar 0,719 satuan dengan asumsi faktor lainnya tetap atau konstan. Perihal ini memperlihatkan kalau naik turunnya kapasitas industri dalam memperoleh keuntungan dalam jenjang aset tertentu, akan berdampak pada naik turunnya nilai perusahaan. Dampak negatif profitabilitas pada nilai perusahaan, bisa disebabkan karena kinerja manajemen industri yang masih belum efektif dan efisien dalam menggunakan aset perusahaan, sehingga laba bersih yang diperoleh menjadi lebih kecil meskipun aset perusahaan sangat besar.

Tujuan pokok industri ialah guna mengoptimalkan profit untuk investor. Setiap perusahaan ingin memperoleh tingkat profitabilitasyang besar. Buat bertahan hidup, industri wajib pada kondisi yang menguntungkan. Jika industri terletak pada keadaan yang kurang menguntungkan, 
alhasil bakal susah buat industri guna mendapatkan investor. Keadaan ini akan mempengaruhi harga saham perusahaan, yang secara langsung bakal berpengaruh pada nilai perusahaan. Selaras dengan studi yang Triagustina, Sukarmanto dan Helliana (2016), yang memperoleh hasil kalau profitabilitas yang dihitung melalui return on asset terbukti berdampak negatif signifikan pada nilai perusahaan. Nilai profitabilitas yang tinggi jika tidak sebanding dengan kepelikan aset perusahaan yang tinggi, tidak akan mendapatkan reaksi pasar. Investor cenderung memilih perusahaan dengan aset yang normal tapi bisa memperoleh profit yang maksimal.

\section{Pengaruh Likuiditas Terhadap Nilai Perusahaan}

Berdasarkan temuan analisis data, diperoleh hasil variabel likuiditas (CR) memperoleh nilai signifikansi sekitar $0,013<0,05$. Artinya likuiditas yang diukur dengan current ratio terbukti berdampak signifikan pada nilai perusahaan di industri pertambangan di BEI, sehingga $\mathrm{H}_{2}$ diterima. Nilai koefisien variabel likuiditas (CR) sebesar 1,160 dengan nilai negatif. Berarti masing-masing peningkatan satu satuan variabel likuiditas, bakal berpengaruh penurunan dalam variabel nilai perusahaan sekitar 1,160 satuan. Hal ini menunjukkan bahwa naik turunnya nilai likuiditas perusahaan memiliki dampak pada naik turunnya nilai perusahaan. Pasar akan merespon apabila perusahaan memiliki likuiditas yang cukup stabil dan cenderung meningkat. Hal ini dikarenakan perusahaan dengan likuditias rendah mempunyai risiko bisnis tinggi yakni tidak mampu membayar hutang dengan aktiva yang ada.

Semua pihak yang berkepentingan dengan perusahaan dapat mengambil untung dari perhitungan rasio likuiditas. Ada banyak orang yang ingin tahu seberapa baik kinerja perusahaan. Debitur perusahaan, sumber dana, seperti bank, dan distributor atau pemasok, yang mendistribusikan atau menjual barang secara mencicil kepada perusahaan, adalah contoh pihak luar yang berkepentingan.. Artinya jika perusahaan mengalami kesulitan likuiditas akan mendapatkan krisis kepercayaan dari pihak yang telah menunjang keberjalanan bisnis. Oleh sebab itu, perhitungan rasio likuiditas juga bermanfaat bagi pihak luar. Dalam praktiknya, analisis rasio likuiditas memiliki banyak manfaat atau visi buat industri serta pihak-pihak yang mempunyai kerja sama dengan industri seperti pemasok dsb. Selaras dengan riset yang dilaksanakan Fajaria dan Isnalita (2018), yang memperoleh hasil kalau likuiditas memiliki pengaruh signifikan pada nilai perusahaan. Perusahaan dengan risiko hutang yang tinggi cenderung dihindari calon investor, karena salah satu tujuan investor menanamkan modalnya yaitu untuk memperoleh keuntungan. Perusahaan yang likuid dianggap memiliki prospek yang baik, sehingga memiliki respon pasar yang baik dan sebaliknya.

\section{Pengaruh Solvabilitas Terhadap Nilai Perusahaan}

Dilihat dari hasil analisis data, solvabilitas yang diukur dengan debt to equity ratio diperoleh nilai sigifikansi sebesar $0,000<0,05$. Solvabilitas terbukti berpengaruh signifikan pada nilai perusahaan pertambangan, sehingga $\mathrm{H}_{3}$ diterima. Nilai koefisien variabel solvabilitas (DER) sebesar 1,354 dengan nilai negatif. Setiap kenaikan satu satuan solvabilitas, dapat berpengaruh pada penurunan pada variabel nilai perusahaan sebesar 1,354 satuan. Rasio solvabilitas yang tinggi maka akan menurunkan nilai perusahaan, karena hutang perusahaan tidak akan mampu tertutupi oleh model perusahaan sehingga nilai perusahaan turun.

Debt to equity ratio (DER) mewakilkan keseimbangan proporsi pada aset yang dibiayai kreditur dan yang dibiayai oleh pemilik perusahaan. DER yang besar maka bertambah besar risiko yang ditanggung perusahaan. DER dapat menunjukkan faktor risiko yang akan diterima investor dan akan mempengaruhi nilai perusahaan. Oleh sebab itu, investor lebih memilih saham dengan DER rendah. Selaras dengan penelitian Sunaryo dan Adiyanto (2017), membuktikan solvabilitas mempunyai pengaruh signifikan pada nilai perusahaan. Perusahaan yang melakukan keputusan pendanaan dengan hutang akan dihindari oleh investor, sebab bunga utang akan mengurangi penghasilan kena pajak sehingga akan menjadi investasi yang sia-sia.

\section{Pengaruh Profitabilitas, Likuiditas dan Solvabilitas Terhadap Nilai Perusahaan}


Berdasarkan hasil analisis data, diketahui nilai signifikansi senilai $0,000<0,05$. Diartikan profitabilitas, likuiditas dan solvabilitas berpengaruh signifikan pada nilai perusahaan pada perusahaan pertambangan di BEI, sehingga $\mathrm{H}_{4}$ diterima. Hal ini menunjukkan bahwa naik turunya nilai profitabilitas, solvabilitas dan solvabilitas memiliki dampak signifikan pada naik turunnya nilai perusahaan. Investor memperhatikan kapabilitas perusahaan untuk memperoleh laba, sebelum menanamkan modalnya. Perusahaan yang tidak mampu melunasi hutang jangka pendek dan sebagian kegiatan operasinya dilakukan dengan hutang cenderung dihindari oleh investor, karena memiliki risiko yang lebih besar.

Selaras dengan penelitian yang dilakukan Markonah, Salim dan Franciska (2020), dimana profitabilitas, likuiditas dan solvabilitas memiliki peran terhadap reaksi pasar yang dapat dilihat pada naik turunnya nilai perusahaan. Perusahaan yang berada dalam posisi kurang menguntungkan, akan menjadi pertimbangan tersendiri bagi calon investor sebelum menanamkan modalnya. Investor juga akan memilih perusahaan dengan likuiditas dan solvabilitas yang baik dan stabil, untuk meminimalisir risiko yang mungkin dapat terjadi. Berdasar hasil pengujian koefisien determinasi, didapat nilai $R$ Square sebesar 0,236 atau sebesar 23,6\%. Hal ini menunjukkan jika nilai perusahaan dapat dijelaskan variabel profitabilitas, likuiditas serta solvabilitas sebesar 23,6\% sedangkan sisanya dijelaskan oleh variabel lain diluar penelitian. Salah satu tujuan investor dalam menanamkan modalnya pada perusahaan yaitu untuk memperoleh keuntungan, sehingga investor akan lebih memiliki perusahaan yang memiliki profitabilitas yang baik dan minim risiko atas hutang.

\section{KESIMPULAN}

Berdasarkan hasil data dan pembahasan, kesimpulannya bahwa variabel profitabilitas, likuditas, dan solvabilitas secara simultan dan partial berpengaruh terhadap nilai perusahaan karena nilai sig < 5\%. Hal ini membuktikan bahwa di perusahaan pertambangan untuk menaikan nilai perusahaan maka harus memperhatikan profitabilitas, likuiditas, dan solvabilitas perusahaan. Kemudian berdasarkan nilai koefisien determinasi menghasilkan R square sebesar 23,6\%, artinya kinerja keuangan perusahaan yakni profitabilitas, likuiditas, dan solvabilitas dapat mempengaruhi nilai perusahaan sebesar $23,6 \%$ sisanya dipengaruhi oleh faktor lain. Hal ini membuat manajemen perusahaan harus memperhatikan kinerja keuangannya guna menjaga nilai perusahaannya.

\section{REFERENSI}

Agustina, S. (2013). Pengaruh Profitabilitas dan Pengungkapan Corporate Social Responbility Terhadap Nilai Perusahaan (Studi Empiris pada Perusahaan Manufaktur yang Terdaftar di Bursa Efek Indonesia). Jurnal Akuntansi, Volume 1 Nomor 1, 1-23.

Anthony, R. N., \& Govindarajan, V. 2007. Management Control Systems (Twelfth Ed). Tata McGraw-Hill Publishing Company Limited McGraw-Hill.

Fajaria, A. Z., \& Isnalita. (2018). The Effect of Profitability, Liquidity, Leverage and Firm Growth of Firm Value with its Dividend Policy as a Moderating Variable. International Journal of Managerial Studies and Research (IJMSR), Volume 6 Nomor 10, 55-69.

Fauzia, N., \& Amanah, L. (2016). Pengaruh Intellectual Capital, Karakteristik Perusahaan, dan Corporate Social Responbility Terhadap Nilai Perusahaan. Jurnal Ilmu dan Riset Akuntansi, Volume 5 Nomor 4, 1-22.

Franita, R. (2018). Mekanisme Good Corporate Governance dan Nilai Perusahaan Studi Untuk Perusahaan Telekominikasi. Medan: Lembaga Penelitian dan Penulisan Ilmiah Aqli.

Gani, I., \& Amalia, S. (2015). Alat Analisis Data; Aplikasi Statistik untuk Penelitian Ekonomi dan Sosial. Yogyakarta: CV. Andi Offset.

Ghozali, I. (2011). Aplikasi Analisis Multivariate Dengan Program SPSS. Semarang: UNDIP Press.

Hery. (2016). Analisis Laporan Keuangan. Jakarta: Grasindo.

Ismanto, H., Widiastut, A., Muharam, H., Pangestuti, I. R., \& Rofiq, F. (2019). Perbankan dan Literasi Keuangan. Yogyakarta: Depublish. 
Kadim, A., \& Sunardi, N. (2019). Pengaruh Profitabilitas, Ukuran Perusahaan Terhadap Leverage Implikasi Terhadap Nilai Perusahaan Cosmetics and Household yang terdaftar di Bursa Efek Indonesia. Jurnal Sekuritas, Volume 3 Nomor 1, 22-32.

Kariyoto. (2017). Analisa Laporan Keuangan. Malang: UB Press.

Kasmir. (2013). Bank dan Lembaga Keuangan Lainnya. Jakarta: PT. Raja Grafindo.

Markonah, M., Salim, A., \& Franciska, J. (2020). Effect Of Profitability, Leverage, And Liquidity To The Firm Value. DIJEFA (Dinasti International Journal Of Economics, FInance \& Accounting), Volume 1 Nomor 1, 83-94.

Ningsih, S., \& Sari, S. P. (2019). Analysis Of The Effect Of Liquidity Ratios, Solvability Ratios And Profitability Ratios On Firm Value In Go Public Companies In The Automotive And Component Sectors. International Journal of Economics, Business and Accounting Research (IJEBAR), Volume 3 Nomor 4, 351-359.

Panggabean, B. F., Lie, D., Jubi, \& Astuti. (2018). Pengaruh Solvabilitas Dan Profitabilitas Terhadap Nilai Perusahaan Pada Perusahaan Sub Sektor Pertambangan Batubara Yang Terdaftar Di Bursa Efek Indonesia. Jurnal FINANCIAL, Volume 4 Nomor 1, 65-72.

Purnomo, R. A. (2017). Analisis Statitsik Ekonomi dan Bisnis dengan SPSS. Ponorogo: CV. Wade Group.

Septiana, A. (2019). Analisis Laporan Keuangan; Konsep Dasar dan Diskripsi Laporan Keuangan. Pamekasan: Duta Media Publishing.

Sukarya, I. P., \& Baskara, I. G. (2019). Pengaruh Profitabilitas, Leverage, Dan Likuiditas Terhadap Nilai Perusahaan Sub Sektor Food And Beverages. E-Jurnal Manajemen, Volume 8 Nomor 1, 7399-7428.

Sunaryo, D., \& Adiyanto, Y. (2017). Pengaruh Debt To Equity Ratio (DER) Dan Deviden Payout Ratio (DPR) Terhadap Nilai Perusahaan Pada Perusahaan Manufaktur Sektor Hasil Industri Untuk Konsumsi Yang Terdaftar Di BEI Tahun 2012-2017. Jurnal Manajemen, Volume 7 Nomor 1, 33-53.

Suyono. (2018). Analisis Regresi untuk Penelitian. Yogyakarta: Deepublish.

Yusuf, M. (2017). Metode Penelitian: Kuantitatif, Kualitatif dan Penelitian Gabungan. Jakarta: Kencana. 